\title{
The Experimental Pathology at Ancona: 50 Years of Exciting and Pioneering Research on Human Pathology
}

\author{
Fabiola Olivieri, Maria Rita Rippo, Laura Graciotti, Armanda Pugnaloni, \\ Francesca Fazioli and Antonio Domenico Procopio
}

\begin{abstract}
Half century ago, a few academic pioneers founded the laboratories of experimental and ultrastructural pathology in Ancona. From this origin, a new phase of experimental studies developed aimed at translational and clinical research up to the present, when our group is internationally recognized for its fundamental contributions in gerontological research and molecular diagnostic pathology. Since the desire of immortality and of eternal youth seems to be as old as mankind, in the future we plan to focus our scientific research on Regenerative Medicine and Rejuvenation strategies. This is the most ambitious aim in the framework of the world aging population. We do not know whether we would achieve these results by ourselves. We are confident that, as in the past, new generations of scientist of the school of experimental pathology at Ancona will get the baton by the older one and lead the future with the same enthusiasm, love and commitment.
\end{abstract}

\section{The Beginnings of Experimental Pathology at the UNIVPM: The Basic and Ultrastructural Research}

The history of Experimental Pathology at Ancona began in the early '70s, when Professor Andrea Corsi was appointed Chairman of General Pathology at the newly created Faculty of Medicine and of which he became Dean. Member of the Accademia dei Lincei, Prof. Corsi had been trained scientifically at the University of Padua where he had conducted pioneering studies on the role of the thymus in the immune system [13, 14, 31]. Prof. Corsi and his collaborators, including Prof. Anna Luisa Granata, Prof. Cesare Vecchi, and Dr. Laura Graciotti, created the first Institute of General

F. Olivieri $(\varangle) \cdot$ M. R. Rippo · L. Graciotti · A. Pugnaloni · F. Fazioli · A. D. Procopio Section of Experimental Pathology and Occupational Medicine, Department of Clinical and Molecular Sciences (DISCLIMO), Università Politecnica Delle Marche, Via Tronto 10/A, Torrette, Ancona, Italy

e-mail: f.olivieri@univpm.it

F. Olivieri · A. D. Procopio

Center of Clinical Pathology and Innovative Therapy, National Institute, IRCCS INRCA, Ancona, Italy 
Pathology and the first Laboratory of Experimental Pathology in Ancona, including a facility for ultrastructural studies equipped with a Philips CM10 electronic microscope. Their efforts allowed the activation of new lines of research on skeletal muscle $[15,16]$ and obtained the first European Community funded research program at our University (MOLECULAR BASIS OF CELL MOVEMENT: Investigation of the fundamental molecular mechanisms of ameboid cell motility and transport using a combination of molecular, cellular and structural biology methods CE-Human and capital mobility CHRX-CT93-0250. 1993-1996). The group was active also on clinical diagnostics. The experimental group founded by Prof. Andrea Corsi at Ancona obtained important results in the study of microcirculation with particular regard to the relationship between capillary blood flow and skeletal muscle function $[17,26$, 35, 68] and in the study of Duchenne Muscular Dystrophy [32]. These later studies demonstrated that cardiac muscle has peculiar molecular defects arising from lack of Dystrophin that suggests different pathogenesis with respect to skeletal muscle. Dystrophin absence lead to a delocalization of KATP channel complex and of Creatine Kinase $M$ the enzymes necessary for the channel correct functioning. Alterations due to dystrophin lack was also investigated in the hippocampus of mdx mice showing alteration in term of cellular and synaptic composition that underlies other muscle unrelated pathogenic mechanism [33].

\section{The Phase of Consolidation: The Translational and Molecular Research}

After Prof. Corsi retired, in 2001 the Faculty appointed Full Professor of General Pathology Professor Antonio Domenico Procopio, a cancer immunologist with a strong background in experimental and clinical pathology. Before reaching Ancona, Prof. Procopio had trained at the La Sapienza University of Rome with Prof. Luigi Frati and at the NCI, Frederick, MD with Dr. Ronald Herberman. He had worked at the NIH, Bethesda, MD where he had conducted pioneering studies on SV40 and mesothelioma and directed the Laboratory of Clinical Pathology at the G. D'Annunzio University of Chieti, Italy. To promote translational and molecular research, short after his arrival to Ancona Prof. Procopio founded the first Department of the Faculty of Medicine (Department of Molecular Pathology and Innovative Therapies, today DISCLIMO), which he directed for many years. More recently, he founded the Center of Clinical Patology and Innovative Therapy at the National Institute on Aging (INRCA), devoted to basic and clinical research, and established the Courses of Clinical Pathology and the Clinical Pathology Residency Program of our Faculty, considered a national excellence.

In those years, Prof. Maria Rita Rippo, a leading immunologist experienced in the mechanisms of programmed cell death, joined the group moving from Rome "La Sapienza". She had worked with Prof. Roberto Testi and Prof. Ruggero De Maria, publishing pioneering studies on the role of FasL and mitochondria in apoptosis 
[20, 21, 64]. Later, other leading scientists permanently joined the Ancona group, including Prof. Francesca Fazioli (molecular oncology) [22, 23] and Prof. Armanda Pugnaloni (cancerology).

Our group refocused its activity on translational research of neoplastic pathologies of mesodermal tissues. Since the first moment of his transfer to Ancona, in the late 90's, Prof. Procopio has continued his studies on pleural malignant mesothelioma (MM). MM, an insidious and still lethal cancer, originates from the mesothelium, which covers the pleura and the others serous cavities such as pericardium, peritoneum, vaginal testis. It is the most common malignant neoplasm of these structures, characterized by a poor prognosis, as it is little responsive to current treatments. MM was found a disease strictly related to asbestos, a harmful natural material endowed with exceptional persistence [40, 41]. During 2000s our group achieved very important results concerning the molecular mechanism responsible of MM progression and the identification of novel diagnostic and prognostic markers. Using different approaches ranging from molecular biology to computational analysis, we have identified several mechanisms of the resistance of MM to chemotherapy, to pro-apoptotic cytokines-induced cell death, and to toxicity of asbestos (Part of the results arise from an Italian Research Project of National Interest-PRIN 2011: "In Vitro Biological Activity and Mechanisms of Lung and Pleural Cancers Induced by Mineral Fibers" [40]. Finally the epigenetic mechanisms involved in MM development and progression has been elucidated [39].

In his early studies on mesothelioma, Procopio and co-workers demonstrated that SV40 (Simian virus-40) plays a role as oncogenic virus and that it is expressed in tissue, urine and blood samples from patients with malignant and non malignant pleural disease $[8,9,73]$. Accordingly, he demonstrated that SV40 sequences are negative prognostic cofactor in patients with malignant pleural mesothelioma [60]. These pioneering researches have paved the way for subsequent studies that have been funded by the Italian Ministries of Health and of Scientific Research and the Italian Association on Cancer Research (AIRC) and have allowed our group to build a network of collaboration with the world's most recognized experts in this field. The following years were therefore rich in discoveries that helped international scientific research to develop and try new strategies for controlling the progression of this cancer, which is still incurable today, and for the therapy of other less aggressive ones. The results obtained prompted AIRC to fund a permanent position of Professor in General Oncology, that has been covered by competitive national examination by Prof. Francesca Fazioli.

The most interesting and cited studies demonstrated that human malignant mesothelioma cells produce autocrine factors promoting their growth and multidrug resistance. Early transforming proteins of SV40, the large tumor antigen (Tag) and the small tumor antigen (tag) induce in mesothelioma cells Vascular endothelial growth factor (VEGF) expression which in turn acts as an autocrine growth factor enhancing their proliferation $[11,73]$. In addition to this proliferative advantage, autocrine production of tyrosine kinase receptor c-Kit and its ligand stem cell factor SCF induces the zinc finger transcription factor Slug and chemoresistance [12]. Therefore, MM 
cells develop a strong resistance to chemotherapy- and immune system-induced programmed cell death because of the overexpression of some anti-apopototic proteins that act at different levels of the extrinsic pro-apoptotic pathway induced by the cytokine FasL/CD95L and to a lesser extent TNF-related apoptosis-inducing ligand (TRAIL) and of the intrinsic one. In particular, we showed that the protein FLIP (FLICE-Inhibitory Protein), which inhibits apoptosis by competing with the procaspase- 8 binding to Fas receptor complex, is constitutively expressed in all MM cell lines and is more expressed in primary MM cells than in normal mesothelial cells [65]. We also demonstrated that MM cells overexpress Bcl-2 and telomerase activity due, at least in part, to Methionine aminopeptidase-2 (MetAP2) expression and function [10]. However, we showed that $\alpha$-tocopheryl succinate ( $\alpha$-TOS), a strong pro-apoptotic agent, can synergize with TRAIL to kill MM via mitochondrial pathway, whereas both of them are nontoxic to normal mesothelial cells [76]. Accordingly, subsequent studies, conducted by other international groups, have shown that FLIP expression is potently downregulated in MM cells in response to the histone deacetylase inhibitor Vorinostat (SAHA), and that this compound overcomes FLIP-mediated inhibition of SMAC mimetic-induced apoptosis in mesothelioma [19].

In the last ten years our research group, which has grown not only in the number of participants but also in the expertise, has expanded the research lines, focusing on the role of epigenetic mechanisms in the development of diseases associated with aging, including tumors. In this context, the study of the role of small non coding RNAs and in particular of miRNAs, as modulators of proteins important in the development and progression of the tumor and markers for the diagnosis and prognosis of malignant mesothelioma, has prevailed over the other epigenetic mechanisms. An interesting research was conducted by our new unit of computational pathology, showing how to manage big miRNA-related data generated by recent technological advances, especially high-throughput sequencing. A number of bio-informatic tools and databases have been devised to manage this growing body of data in diverse areas of miRNA research, to assist investigators in choosing the most appropriate tools for their needs [1]. Since miRNAs have established diagnostic value in cancer and pollution exposure and, furthermore, minimally invasive, specific and sensitive biomarkers for early and effective diagnosis of MM in high-risk patients are urgently needed, computational pathology unit identified high-confidence miRNAs that can serve as biomarkers of asbestos exposure and MM by a systematic review and a qualitative meta-analysis. In particular, two miRNA signatures of deregulated circulating (miR-126-3p, miR-103a-3p, and miR-625-3p) and tissue (miR-16-5p, miR-126-3p, miR-143-3p, miR-145-5p, miR-192-5p, miR-193a-3p, miR-200b-3p, miR-203a-3p, and miR-652-3p) miRNAs were identified with potential early diagnostic value and designated as "mesomiRs" [39]. A large-scale, standardized validation studies are ongoing to assess their clinical relevance, so as to move from the workbench to the clinic. 


\section{The New Program on Aging and Age-Related Diseases (ARDs): Identification and Characterization of Innovative Biomarkers of Aging and ARDs}

Due to the increased lifespan, the demographic patterns and the ageing of the European and Italian population is changing. A new line of research focused on the identification of innovative genetic and epigenetic biomarkers of aging and age-related human diseases (ARDs) was launched in 2007, in the framework of the research activity of the Experimental Pathology team. Under the leadership of Professor Fabiola Olivieri the group have pioneered this topic. Prof. Olivieri, before joining our Group in Ancona as a leading gerontologist, was trained scientifically at "Alma Mater Studiorum" University of Bologna, and worked at INRCA, the national Italian Institute on Aging, with Prof. C. Franceschi. Her guide successfully finalized our efforts to achieve the objectives of this ambitious project, requiring a comprehensive knowledge of ageing processes not only at the medical-clinical level, but also at the level of the biological and molecular mechanisms (genetic, epigenetic, hormonal) that underlie healthy ageing. Applying a multidisciplinary approach, integrating the expertise in different areas, such as clinical pathology, oncology, cardiology, molecular biology, genetic, biostatistics and computational analysis, our research group was involved in a number of national and international collaborative projects, supported by Operative Regional Program (POR) Marche, Italian Ministry of Education-Universities and Research (MIUR), Italian Ministry of Health and projects co-founded by European countries. Within this framework, in the last 10 years, we have been able to publish more than 150 articles (that received more than 10,000 citations, Scopus, 2018) in peer-reviewed top-ranking international journals.

The conceptualization that underlies these studies is that "ageing" is not a static but rather a dynamic phenotype that changes over time; a continuous interaction between individuals' genetic makeup and environmental factors results in a spectrum of states that range from healthy ageing to ARDs. This dynamic interaction drives an age-related remodelling of a number of pathways/systems, providing the chance to reach the extreme limit of human life in healthy state, which is reflected in the ever-increasing number of centenarians $[6,28,70]$. If a continuum between unhealthy and healthy ageing exists, the major chronic ARDs should be conceptualized and studied within the framework of the ageing process and its basic molecular and cellular mechanisms. This conceptualization implies that aging process per se and the development of the most common ARDs are somewhat separate but must share somehow common set of basic biological mechanisms, mainly the development and progression of an inflammatory state named inflammaging, an increased burden of senescent cells and a defective cellular cross-talk [27]. Some years ago we advanced a general hypothesis that the ageing process and the development of ARDs could be fostered by a low-grade, chronic inflammatory process that was designated inflammaging [24]. A number of data suggest that this process is sustained by pro-inflammatory cells and circulating compounds $[25,58,59]$. Notably, the rate 
of inflammaging progression is currently recognized as the main force driving aging and one of the main risk factors for clinical morbidity and mortality in the elderly [27].

Since ageing involves the entire organism, it is conceivable that preservation of a health state during ageing is ensured by efficient tissue and organ crosstalk. Based on this hypothesis age-related health deterioration would stem from defective tissue and organ crosstalk. Molecules circulating in the bloodstream would be the main culprits: studies of their expression and of the pathways they target have the potential to provide information on the ageing process and healthy/non-healthy ageing trajectories [43]. Circulating extracellular nucleic acids were first described in the human bloodstream more than 50 years ago. However, quite recent evidence suggests that circulating RNA/DNA and their shuttles (exosomes and protein/lipoproteins) constitute a new efficient system for inter-tissue and inter-organ crosstalk as well as an integrated reservoir of information relating to all body tissues and organs. These biomarkers are expected to be informative, easily accessible, and cost-effective candidate biomarkers of the ageing process, enabling assessment of the health status of individuals both at the level of specific tissues/organs and at the systemic one [44]. Importantly, their different shuttles could affect the efficiency of delivery to target cells, hence their biological effects [57]. Rather than a single miRNA or cf-DNA sequence, combinations of molecules associated with specific shuttles (signatures) are expected to be relevant to the pathogenesis, prediction, diagnosis and prognosis of the major human ARDs. Based on these hypotheses and the integrated and complementary expertise of the General Pathology team, an integrated series of studies was conducted to test the ability of miRNA/cf-DNA signatures and their shuttles to be robust predictive/prognostic biomarkers of the most common ARDs, i.e. type 2 diabetes (T2DM), cardiovascular disease (CVD), tumors and neurodegenerative diseases [46]. We analysed existing sample collections from a number of case-control studies nested in cohort studies and longitudinal studies, including healthy individuals of different ages ranging from healthy young subjects to centenarians and their offspring, and non-healthy individuals ranging from obese adults to patients affected by CVD [47, 49, 50], T2DM [45, 58], and neurodegenerative diseases (AD, NAD).

One of the clinically relevant result on circulating miRNAs concerns the diagnostic performance of miR-499-5p in acute non-ST elevation myocardial infarction (NSTEMI) in the elderly. Circulating miR-499-5p exhibited a diagnostic accuracy superior to that of troponin in patients with modest elevation at presentation [49]. Admission levels of circulating miR-499-5p were also associated with the risk of death in elderly patients after acute NSTEMI [47]. A recent systematic review confirmed the clinical relevance of miR-499-5p for diagnosis of cardiovascular disease [42].

Finally, we also investigated the effect of anti-aging treatments on miRNAs expression, both in vivo and in vitro. A study on postmenopausal monozygotic twin pairs showed that hormone replacement therapy was able to enhance IGF-1 signaling in skeletal muscle by diminishing miR-182 and miR-223 expressions [48]. The antiinflammatory effect of ubiquinol-10 was analysed in endothelial cells showing that miR-146a modulation was induced by this treatment [51]. 
Prof. Massimo Re, otolaryngology Unit, also made collaborative studies on expression levels and clinical significance of specific miRNAs (miR-21-5p, miRlet-7a, and miR-34c-5p) in Laryngeal Squamous Cell Carcinoma [61, 62],

Ex vivo studies were paralleled to in vitro data on cellular models [52]. Our results suggest that miRNAs involved in the modulation of inflammatory processes and in the acquisition of "senescence phenotype" in senescent endothelial cells, fibroblasts and circulating cells may play a role in propagating cell senescence and inflammaging, thus being biomarkers of risk to develop the most common ARDs. In a paper published in 2013 we named these circulating miRNA-based signatures as "inflamma-miRs" [53].

In addition to miRNAs, we analysed a number of senescence associated biomarkers, i.e. telomere length [5, 7, 38, 53, 55, 56, 74], telomerase activity [55], RNAseH2 activity [71], beta-galactidase activity [69], DNA methylation status [4], M1/M2 circulating balancing [18] and n-glycomic changes in serum proteins [75]. The results of these studies, conducted on healthy subjects of different age and in patients affected by ARDs, support the view that the most common ARDs are characterized by an "accelerated aging phenotype".

Increasing attention is currently devoted to vesicles released by living cells in the bloodstream, that can vary in size, origin and content. The best characterized vesicles are those derived from plasmatic membrane blabbing, named micro-vesicles (MVs) and those derived from multi-vesicular bodies (MVBs), named exosomes (EXs). EXs and MVs can represent a cleaner source of information, since circulating MVs-packaged information (i.e. miRNAs, proteins, DNA fragments) in addition to their role as biomarkers, act as functional mediators being involved in the cellular crosstalk. The informative potential, role and specificity of circulating miRNAs/cfDNA, and their shuttles required a comprehensive experimental design involving a highly integrated ex vivo and in vitro approach [54, 57]. We are currently studying the cargos composition of exosomes and microvescicles circulating in plasma of patients affected by the most common age-related diseases (i.e. cancer, CVD and T2DM) and comorbidities (hypertension, frailty), as well as vesicles-based signatures released by senescent cells (endothelial cells, cancer cells, fibroblasts), in order to identify "senescence-associated vesicle profiles" that could represent an innovative approach of "liquid biopsy" in the framework of aging.

Another recently intriguingly hypothesis is that cytoplasmic (cy) and cell-free (cf) DNA pools trigger inflammation and innate immunity at local and systemic level. In particular, cyDNA could play a crucial role in the phenomenon of cell senescence and in the cognate pro-inflammatory secretome [72].

Since epigenetic modifications are reversible, affecting gene expression without altering the DNA sequence, recently we activated a line of research aimed to assess the impact of lifestyles, such as exercise and diet, on aging processes [2, 3, 34, 63]. Although in vivo detection and targeting of senescent cells are still being investigated, it is likely that therapeutic strategies based on antioxidant and anti-inflammatory compounds would involve generalized anti-aging effects [59]. Although considerable work is still required to explore the toxicity profile and the extent of the benefits 
provided by natural and synthetic anti-aging compounds, nutritional approaches are expected to provide new tools to combat ARDs.

Under the guidance of Prof. Maria Rita Rippo, the research group has also highlighted mechanisms of resistance to programmed cell death of senescent cells and on those that regulate the differentiation of mesenchymal stromal cells (MSCs) which show alterations in their proliferative and differentiating capacity in elderly [77]. In particular, for the first time we suggested and demonstrated that mito-miRs (mitochondria resident or associated to mitochondrial membranes) are modulated and can control expression of Bcl-2 family members and the oxidative and energetic status in aging cells thus contributing to their resistance to pro-apoptotic stimuli, pro-inflammatory phenotype and altered autophagy [29, 30, 67]. Furthermore, our group demonstrated that FasL, whose circulating levels decrease progressively during aging [36], is modulated in post-menopausal women [37] and play a pivotal role in bone homeostasis inhibiting MSCs differentiation in adipocytes and inducing their proliferation [66]. These data are interesting in the light of the imbalance between adipocytes, osteoblasts and MSCs existing within the bone marrow of aged people suffering of osteoporosis.

\section{Future Perspective}

The desire of eternal youth seems to be as old as mankind, as documented in ancient literature. Organ and tissue loss through disease and injury motivate the effort to develop therapies that can regenerate tissues and decrease reliance on transplantations. Regenerative medicine can potentially restore diseased and injured tissues and whole organs. We plan first to slow the aging processes and postpone the development of the most common age-related diseases, and after to push forward humanity lifespan. We do not know where the next fifty years would bring our scientific research. We already made the choice to track our technological path through Regenerative Medicine, Rejuvenation, Robotics, and Computational Pathology, and we are developing the skills needed for that. What is very clear to us is that in the past 50 years it was possible to build up a free, positive, and creative environment which our young colleagues begun to refer as "the school of Ancona of experimental pathology". We are confident that within this environment, the new generation of scientists that here and abroad is blooming will very soon get the baton by the older one and lead the future with the same enthusiasm, love and commitment. 


\section{References}

1. Akhtar MM, Micolucci L, Islam MS, Olivieri F, Procopio AD (2016) Bioinformatic tools for microRNA dissection. Nucleic Acids Res 44:24-44

2. Antonicelli R, Spazzafumo L, Scalvini S, Olivieri F, Matassini MV, Parati G, Del Sindaco D, Gallo R, Lattanzio F (2016) Exercise: a "new drug" for elderly patients with chronic heart failure. Aging (Albany NY). 8:860-872

3. Bacalini MG, Friso S, Olivieri F, Pirazzini C, Giuliani C, Capri M, Santoro A, Franceschi C, Garagnani P (2014) Present and future of anti-ageing epigenetic diets. Mech Ageing Dev 136-137:101-115

4. Bacalini MG, Deelen J, Pirazzini C, De Cecco M, Giuliani C, Lanzarini C, Ravaioli F, Marasco E, van Heemst D, Suchiman HED, Slieker R, Giampieri E, Recchioni R, Marcheselli F, Salvioli S, Vitale G, Olivieri F, Spijkerman AMW, Dollé MET, Sedivy JM, Castellani G, Franceschi C, Slagboom PE, Garagnani P (2017) Systemic age-associated DNA hypermethylation of ELOVL2 gene. In vivo and in vitro evidences of a cell replication process. J Gerontol A Biol Sci Med Sci 72:1015-1023

5. Bonfigli AR, Spazzafumo L, Prattichizzo F, Bonafè M, Mensà E, Micolucci L, Giuliani A, Fabbietti P, Testa R, Boemi M, Lattanzio F, Olivieri F (2016) Leukocyte telomere length and mortality risk in patients with type 2 diabetes. Oncotarget 732:50835-50844

6. Capri M, Santoro A, Garagnani P, Bacalini MG, Pirazzini C, Olivieri F, Procopio A, Salvioli S, Franceschi C (2014) Genes of human longevity: an endless quest? Curr Vasc Pharmacol 12:707-717

7. Capri M, Olivieri F, Lanzarini C, Remondini D, Borelli V, Lazzarini R, Graciotti L, Albertini MC, Bellavista E, Santoro A, Biondi F, Tagliafico E, Tenedini E, Morsiani C, Pizza G, Vasuri F, D'Errico A, Dazzi A, Pellegrini S, Magenta A, D'Agostino M, Capogrossi MC, Cescon M, Rippo MR, Procopio AD, Franceschi C, Grazi GL (2017) Identification of miR-31-5p, miR141-3p, miR-200c-3p, and GLT1 as human liver aging markers sensitive to donor-recipient age-mismatch in transplants. Aging Cell 16:262-272

8. Carbone M, Pass HI, Rizzo P, Marinetti M, Di Muzio M, Mew DJ, Levine AS, Procopio A (1994) Simian virus 40-like DNA sequences in human pleural mesothelioma. Oncogene 6:1781-1790

9. Carbone M, Rizzo P, Grimley PM, Procopio A, Mew DJ, Shridhar V, de Bartolomeis A, Esposito V, Giuliano MT, Steinberg SM, Levine AS, Giordano A, Pass HI (1997) Simian virus-40 large-T antigen binds p53 in human mesotheliomas. Nat Med 8:908-912

10. Catalano A, Romano M, Robuffo I, Strizzi L, Procopio A (2001) Methionine aminopeptidase-2 regulates human mesothelioma cell survival: role of Bcl-2 expression and telomerase activity. Am J Pathol 159:721-731

11. Catalano A, Romano M, Martinotti S, Procopio A (2002) Enhanced expression of vascular endothelial growth factor (VEGF) plays a critical role in the tumor progression potential induced by simian virus 40 large T antigen. Oncogene 21:2896-2900

12. Catalano A, Rodilossi S, Rippo MR, Caprari P, Procopio A (2004) Induction of stem cell factor/c-Kit/slug signal transduction in multidrug-resistant malignant mesothelioma cells. J Biol Chem 279:46706-46714

13. Corsi A, Giusti GV (1967) Cellular distribution in the bone marrow after thymectomy. Nature 216:493-494

14. Corsi A, Giusti GV (1967) Phagocytic activity after thymectomy. Nature 213:618-619

15. Corsi A, Granata AL, Vecchi C, Strabbioli R, Re L (1988) Variation in thin filament size in the skeletal muscle of the frog. J Cell Sci 90:569-575

16. Corsi A, Midrio M, Granata AL, Corgnati A, Wolf D (1972) Lactate oxidation by skeletal muscle in vivo after denervation. Am J Physiol 223:219-222

17. Corsi A, Granata AL, Hudlicka O (1990) Effect of activity on performance and morphology in ischaemic rat slow muscles. J Exp Biol 152:265-279 
18. Costantini A, Viola N, Berretta A, Galeazzi R, Matacchione G, Sabbatinelli J, Storci G, De Matteis S, Butini L, Rippo MR, Procopio AD, Caraceni D, Antonicelli R, Olivieri F, Bonafè M (2018) Age-related M1/M2 phenotype changes in circulating monocytes from healthy/unhealthy individuals. Aging (Albany NY) 10:1268-1280

19. Crawford N, Stasik I, Holohan C, Majkut J, McGrath M, Johnston PG, Chessari G, Ward GA, Waugh DJ, Fennell DA, Longley DB (2013) SAHA overcomes FLIP-mediated inhibition of SMAC mimetic-induced apoptosis in mesothelioma. Cell Death Dis 4:e733

20. De Maria R, Rippo MR, Schuchman EH, Testi R (1998) Acidic sphingomyelinase (ASM) is necessary for fas-induced GD3 ganglioside accumulation and efficient apoptosis of lymphoid cells. J Exp Med 187:897-902

21. De Maria R, Lenti L, Malisan F, d'Agostino F, Tomassini B, Zeuner A, Rippo MR, Testi R (1997) Requirement for GD3 ganglioside in CD95- and ceramide-induced apoptosis. Science 277:1652-1655

22. Fazioli F, Bottaro DP, Minichiello L, Auricchio A, Wong WT, Segatto O, Di Fiore PP (1992) Identification and biochemical characterization of novel putative substrates for the epidermal growth factor receptor kinase. J Biol Chem 267:5155-5161

23. Fazioli F, Minichiello L, Matoska V, Castagnino P, Miki T, Wong WT, Di Fiore PP (1993) Eps8, a substrate for the epidermal growth factor receptor kinase, enhances EGF-dependent mitogenic signals. EMBO J 12:3799-3808

24. Franceschi C, Bonafè M, Valensin S, Olivieri F, De Luca M, Ottaviani E, De Benedictis G (2000) Inflamm-aging. An evolutionary perspective on immunosenescence. Ann N Y Acad Sci 908:244-254. Review

25. Franceschi C, Capri M, Monti D, Giunta S, Olivieri F, Sevini F, Panourgia MP, Invidia L, Celani L, Scurti M, Cevenini E, Castellani GC, Salvioli S (2007) Inflammaging and anti-inflammaging: a systemic perspective on aging and longevity emerged from studies in humans. Mech Ageing Dev 128:92-105

26. Fulgenzi G, Graciotti L, Corsi A, Granata AL (2001) Reversible binding of glycolytic enzymes and size change in the actin-containing filaments of the frog skeletal muscle. J Muscle Res Cell Motil 22:391-397

27. Fulop T, Witkowski JM, Olivieri F, Larbi A (2018) The integration of inflammaging in agerelated diseases. Semin Immunol 40:17-35

28. Garagnani P, Giuliani C, Pirazzini C, Olivieri F, Bacalini MG, Ostan R, Mari D, Passarino G, Monti D, Bonfigli AR, Boemi M, Ceriello A, Genovese S, Sevini F, Luiselli D, Tieri P, Capri M, Salvioli S, Vijg J, Suh Y, Delledonne M, Testa R, Franceschi C (2013) Centenarians as super-controls to assess the biological relevance of genetic risk factors for common age-related diseases: a proof of principle on type 2 diabetes. Aging (Albany NY) 5:373-385

29. Giuliani A, Prattichizzo F, Micolucci L, Ceriello A, Procopio AD, Rippo MR (2017) Mitochondrial (Dys) function in inflammaging: do MitomiRs influence the energetic, oxidative, and inflammatory status of senescent cells? Mediators Inflamm 2017:2309034

30. Giuliani A, Cirilli I, Prattichizzo F, Mensà E, Fulgenzi G, Sabbatinelli J, Graciotti L, Olivieri F, Procopio AD, Tiano L, Rippo MR (2018) The mitomiR/Bcl-2 axis affects mitochondrial function and autophagic vacuole formation in senescent endothelial cells. Aging (Albany NY) 10:2855-2873

31. Giusti GV, Corsi A (1967) Storage of colloidal carbon in liver and spleen after thymectomy. Nature 214:916

32. Graciotti L, Becker J, Granata AL, Procopio AD, Tessarollo L, Fulgenzi G (2011) Dystrophin is required for the normal function of the cardio-protective K(ATP) channel in cardiomyocytes. PLoS ONE 6:e27034

33. Graciotti L, Minelli A, Minciacchi D, Procopio A, Fulgenzi G (2008) GABAergic miniature spontaneous activity is increased in the CA1 hippocampal region of dystrophic mdx mice. Neuromuscul Disord 18:220-226

34. Gurău F, Baldoni S, Prattichizzo F, Espinosa E, Amenta F, Procopio AD, Albertini MC, Bonafè M, Olivieri F (2018) Anti-senescence compounds: a potential nutraceutical approach to healthy aging. Ageing Res Rev 46:14-31 
35. Hudlicka O, Graciotti L, Fulgenzi G, Brown MD, Egginton S, Milkiewicz M, Granata AL (2003) The effect of chronic skeletal muscle stimulation on capillary growth in the rat: are sensory nerve fibres involved? J Physiol 546:813-822

36. Ichikura T, Majima T, Uchida T, Okura E, Ogawa T, Mochizuki H (2001) Plasma soluble Fas ligand concentration: decrease in elderly men and increase in patients with gastric carcinoma. Oncol Rep 8:311-314

37. Kangas R, Pöllänen E, Rippo MR, Lanzarini C, Prattichizzo F, Niskala P, Jylhävä J, Sipilä S, Kaprio J, Procopio AD, Capri M, Franceschi C, Olivieri F, Kovanen V (2014) Circulating miR21, miR-146a and Fas ligand respond to postmenopausal estrogen-based hormone replacement therapy-a study with monozygotic twin pairs. Mech Ageing Dev 143-144:1-8

38. Mensà $\mathrm{E}$, Latini $\mathrm{S}$, Ramini $\mathrm{D}$, Storci $\mathrm{G}$, Bonafè $\mathrm{M}$, Olivieri $\mathrm{F}$ (2019) The telomere world and aging: analytical challenges and future perspectives. Ageing Res Rev. https://doi.org/10.1016/ j.arr.2019.01.004

39. Micolucci L, Akhtar MM, Olivieri F, Rippo MR, Procopio AD (2016) Diagnostic value of microRNAs in asbestos exposure and malignant mesothelioma: systematic review and qualitative meta-analysis. Oncotarget 7:58606-58637

40. Mossman BT, Pugnaloni A (2017) In vitro biological activity and mechanisms of lung and pleural cancers induced by mineral fibres. EMU Notes Mineral 18(8):261-306. www. minersoc.org

41. Mossman BT, Pugnaloni A (2017) Mineral fibres: crystal chemistry, chemical-physical properties, biological interaction and toxicity. European Mineralogical Union and the Mineralogical Society of Great Britain \& Ireland, London

42. Navickas R, Gal D, Laucevičius A, Taparauskaitė A, Zdanytè M, Holvoet P (2016) Identifying circulating microRNAs as biomarkers of cardiovascular disease: a systematic review. Cardiovasc Res 111:322-337

43. Olivieri F, Prattichizzo F, Grillari J, Balistreri CR (2018) Cellular senescence and inflammaging in age-related diseases. Mediators Inflamm 17(2018):9076485

44. Olivieri F, Albertini MC, Orciani M, Ceka A, Cricca M, Procopio AD, Bonafè M (2015) DNA damage response (DDR) and senescence: shuttled inflamma-miRNAs on the stage of inflamm-aging. Oncotarget 6:35509-35521

45. Olivieri F, Spazzafumo L, Bonafè M, Recchioni R, Prattichizzo F, Marcheselli F, Micolucci L, Mensà E, Giuliani A, Santini G, Gobbi M, Lazzarini R, Boemi M, Testa R, Antonicelli R, Procopio AD, Bonfigli AR (2015) MiR-21-5p and miR-126a-3p levels in plasma and circulating angiogenic cells: relationship with type 2 diabetes complications. Oncotarget 6:35372-35382

46. Olivieri F, Procopio AD, Montgomery RR (2014) Effect of aging on microRNAs and regulation of pathogen recognition receptors. Curr Opin Immunol 29:29-37. https://doi.org/10.1016/j.coi. 2014.03.006

47. Olivieri F, Ahtiainen M, Lazzarini R, Pöllänen E, Capri M, Lorenzi M, Fulgenzi G, Albertini MC, Salvioli S, Alen MJ, Kujala UM, Borghetti G, Babini L, Kaprio J, Sipilä S, Franceschi C, Kovanen V, Procopio AD (2014) Hormone replacement therapy enhances IGF-1 signaling in skeletal muscle by diminishing miR-182 and miR-223 expressions: a study on postmenopausal monozygotic twin pairs. Aging Cell 13:850-861

48. Olivieri F, Antonicelli R, Spazzafumo L, Santini G, Rippo MR, Galeazzi R, Giovagnetti S, D'Alessandra Y, Marcheselli F, Capogrossi MC, Procopio AD (2014) Admission levels of circulating miR-499-5p and risk of death in elderly patients after acute non-ST elevation myocardial infarction. Int J Cardiol 172:e276-e278

49. Olivieri F, Antonicelli R, Lorenzi M, D’Alessandra Y, Lazzarini R, Santini G, Spazzafumo L, Lisa R, La Sala L, Galeazzi R, Recchioni R, Testa R, Pompilio G, Capogrossi MC, Procopio AD (2013) Diagnostic potential of circulating miR-499-5p in elderly patients with acute non ST-elevation myocardial infarction. Int J Cardiol 31(167):531-536

50. Olivieri F, Antonicelli R, Capogrossi MC, Procopio AD (2013) Circulating microRNAs (miRs) for diagnosing acute myocardial infarction: an exciting challenge. Int J Cardiol 167:3028-3029

51. Olivieri F, Lazzarini R, Babini L, Prattichizzo F, Rippo MR, Tiano L, Di Nuzzo S, Graciotti L, Festa R, Brugè F, Orlando P, Silvestri S, Capri M, Palma L, Magnani M, Franceschi C, Littarru 
GP, Procopio AD (2013) Anti-inflammatory effect of ubiquinol-10 on young and senescent endothelial cells via miR-146a modulation. Free Radic Biol Med 63:410-420

52. Olivieri F, Lazzarini R, Recchioni R, Marcheselli F, Rippo MR, Di Nuzzo S, Albertini MC, Graciotti L, Babini L, Mariotti S, Spada G, Abbatecola AM, Antonicelli R, Franceschi C, Procopio AD (2013) MiR-146a as marker of senescence-associated pro-inflammatory status in cells involved in vascular remodelling. Age (Dordr). 35:1157-1172

53. Olivieri F, Rippo MR, Procopio AD, Fazioli F (2013) Circulating inflamma-miRs in aging and age-related diseases. Front Genet. 26(4):121

54. Olivieri F, Antonicelli R, Recchioni R, Mariotti S, Marcheselli F, Lisa R, Spazzafumo L, Galeazzi R, Caraceni D, Testa R, Latini R, Procopio AD (2013) Telomere/telomerase system impairment in circulating angiogenic cells of geriatric patients with heart failure. Int J Cardiol 164:99-105

55. Olivieri F, Mazzanti I, Abbatecola AM, Recchioni R, Marcheselli F, Procopio AD, Antonicelli R (2012) Telomere/telomerase system: a new target of statins pleiotropic effect? Curr Vasc Pharmacol 10:216-224

56. Olivieri F, Lorenzi M, Antonicelli R, Testa R, Sirolla C, Cardelli M, Mariotti S, Marchegiani F, Marra M, Spazzafumo L, Bonfigli AR, Procopio A (2009) Leukocyte telomere shortening in elderly Type2DM patients with previous myocardial infarction. Atherosclerosis 206:588-593

57. Prattichizzo F, Micolucci L, Cricca M, De Carolis S, Mensà E, Ceriello A, Procopio AD, Bonafè M, Olivieri F (2017) Exosome-based immunomodulation during aging: a nano-perspective on inflamm-aging. Mech Ageing Dev 168:44-53

58. Prattichizzo F, Giuliani A, De Nigris V, Pujadas G, Ceka A, La Sala L, Genovese S, Testa R, Procopio AD, Olivieri F, Ceriello A (2016a) Extracellular microRNAs and endothelial hyperglycaemic memory: a therapeutic opportunity? Diabetes Obes Metab 18:855-867. Review

59. Prattichizzo F, Bonafè M, Ceka A, Giuliani A, Rippo MR, Re M, Antonicelli R, Procopio AD, Endothelial Olivieri F (2016) Cell senescence and inflammaging: microRNAs as biomarkers and innovative therapeutic tools. Curr Drug Targets 17:388-397

60. Procopio A, Strizzi L, Vianale G, Betta P, Puntoni R, Fontana V, Tassi G, Gareri F, Mutti L (2000) Simian virus-40 sequences are a negative prognostic cofactor in patients with malignant pleural mesothelioma. Genes Chromosomes Cancer 29:173-179

61. Re M, Magliulo G, Gioacchini FM, Bajraktari A, Bertini A, Çeka A, Rubini C, Ferrante L, Procopio AD, Olivieri F (2017) Expression levels and clinical significance of miR-21-5p, miRlet-7a, and miR-34c-5p in laryngeal squamous cell carcinoma. Biomed Res Int 2017:3921258

62. Re M, Çeka A, Rubini C, Ferrante L, Zizzi A, Gioacchini FM, Tulli M, Spazzafumo L, SellariFranceschini S, Procopio AD, Olivieri F (2015) MicroRNA-34c-5p is related to recurrence in laryngeal squamous cell carcinoma. Laryngoscope 125:E306-E312

63. Recchioni R, Marcheselli F, Antonicelli R, Mensà E, Lazzarini R, Procopio AD, Olivieri F (2017) Epigenetic effects of physical activity in elderly patients with cardiovascular disease. Exp Gerontol 100:17-27

64. Rippo MR, Malisan F, Ravagnan L, Tomassini B, Condo I, Costantini P, Susin SA, Rufini A, Todaro M, Kroemer G, Testi R (2000) GD3 ganglioside directly targets mitochondria in a bcl-2-controlled fashion. FASEB J 14:2047-2054

65. Rippo MR, Moretti S, Vescovi S, Tomasetti M, Orecchia S, Amici G, Catalano A, Procopio A (2004) FLIP overexpression inhibits death receptor-induced apoptosis in malignant mesothelial cells. Oncogene 23:7753-7760

66. Rippo MR, Babini L, Prattichizzo F, Graciotti L, Fulgenzi G, Tomassoni Ardori F, Olivieri F, Borghetti G, Cinti S, Poloni A, Fazioli F, Procopio AD (2013) Low FasL levels promote proliferation of human bone marrow-derived mesenchymal stem cells, higher levels inhibit their differentiation into adipocytes. Cell Death Dis 4:e594

67. Rippo MR, Olivieri F, Monsurrò V, Prattichizzo F, Albertini MC, Procopio AD (2014) MitomiRs in human inflamm-aging: a hypothesis involving miR-181a, miR-34a and miR-146a. Exp Gerontol 56:154-163 
68. Rivero F, Albrecht R, Dislich H, Bracco E, Graciotti L, Bozzaro S, Noegel AA (1999) RacF1, a novel member of the Rho protein family in Dictyostelium discoideum, associates transiently with cell contact areas, macropinosomes, and phagosomes. Mol Biol Cell 10:1205-1219

69. Spazzafumo L, Mensà E, Matacchione G, Galeazzi T, Zampini L, Recchioni R, Marcheselli F, Prattichizzo F, Testa R, Antonicelli R, Garagnani P, Boemi M, Bonafè M, Bonfigli AR, Procopio AD, Olivieri F (2017) Age-related modulation of plasmatic beta-galactosidase activity in healthy subjects and in patients affected by T2DM. Oncotarget 8(55):93338-93348

70. Spazzafumo L, Olivieri F, Abbatecola AM, Castellani G, Monti D, Lisa R, Galeazzi R, Sirolla C, Testa R, Ostan R, Scurti M, Caruso C, Vasto S, Vescovini R, Ogliari G, Mari D, Lattanzio F, Franceschi C (2013) Remodelling of biological parameters during human ageing: evidence for complex regulation in longevity and in type 2 diabetes. Age (Dordr). 35:419-429

71. Storci G, De Carolis S, Papi A, Bacalini MG, Gensous N, Marasco E, Tesei A, Fabbri F, Arienti C, Zanoni M, Sarnelli A, Santi S, Olivieri F, Mensà E, Latini S, Ferracin M, Salvioli S, Garagnani P, Franceschi C, Bonafè M (2019) Genomic stability, anti-inflammatory phenotype, and up-regulation of the RNAseH2 in cells from centenarians. Cell Death Differ. https://doi. org/10.1038/s41418-018-0255-8

72. Storci G, De Carolis S, Olivieri F, Bonafè M (2018) Changes in the biochemical taste of cytoplasmic and cell-free DNA are major fuels for inflamm-aging. Semin Immunol 40:6-16

73. Strizzi L, Catalano A, Vianale G, Orecchia S, Casalini A, Tassi G, Puntoni R, Mutti L, Procopio A (2001) Vascular endothelial growth factor is an autocrine growth factor in human malignant mesothelioma. J Pathol 193:468-475

74. Testa R, Olivieri F, Sirolla C, Spazzafumo L, Rippo MR, Marra M, Bonfigli AR, Ceriello A, Antonicelli R, Franceschi C, Castellucci C, Testa I, Procopio AD (2011) Leukocyte telomere length is associated with complications of type 2 diabetes mellitus. Diabet Med 28:1388-1394

75. Testa R, Vanhooren V, Bonfigli AR, Boemi M, Olivieri F, Ceriello A, Genovese S, Spazzafumo L, Borelli V, Bacalini MG, Salvioli S, Garagnani P, Dewaele S, Libert C, Franceschi C (2015) $\mathrm{N}$-glycomic changes in serum proteins in type 2 diabetes mellitus correlate with complications and with metabolic syndrome parameters. PLoS ONE 10:e0119983

76. Tomasetti M, Rippo MR, Alleva R, Moretti S, Andera L, Neuzil J, Procopio A (2004) Alphatocopheryl succinate and TRAIL selectively synergise in induction of apoptosis in human malignant mesothelioma cells. Br J Cancer 90:1644-1653

77. Wilson A, Shehadeh LA, Yu H, Webster KA (2010) Age-related molecular genetic changes of murine bone marrow mesenchymal stem cells. BMC Genom 11:229 